\title{
DEVELOPMENT OF THE NEW METHOD OF THE MELTED CHEESE PRODUCTS WITHOUT SALT-MELTERS USING CRYOMECHANOLYSIS
}

\author{
Raisa Pavlyuk \\ Department of Technology processing of fruits, vegetables and milk \\ Kharkiv State University of Food Technology and Trade \\ 333 Klochkivska str., Kharkiv, Ukraine, 61051 \\ ktppom@ukr.net \\ Viktoriya Pogarska \\ Department of Technology processing of fruits, vegetables and milk \\ Kharkiv State University of Food Technology and Trade \\ 333 Klochkivska str., Kharkiv, Ukraine, 61051 \\ ktppom@ukr.net \\ Olga Yurieva \\ Department of Technology processing of fruits, vegetables and milk \\ Kharkiv State University of Food Technology and Trade \\ 333 Klochkivska str., Kharkiv, Ukraine, 61051 \\ ktppom@ukr.net \\ Lidia Skripka \\ Kharkiv college processing and food industries KNUA P. Vasilenko \\ 51 Barikadnaya str., Kharkiv, Ukraine, 61200 \\ kphphntusg@mail.ru \\ Tatyana Abramova \\ Kharkiv college processing and food industries KNUA P. Vasilenko \\ 51 Barikadnaya str., Kharkiv, Ukraine, 61200 \\ kphphntusg@mail.ru
}

\footnotetext{
Abstract

The aim of the work is elaboration of the principally new method of deep processing of rennet cheeses to the melting using the complex action of freezing and cryomechanolysis on the raw material that gives a possibility to destruct the hardly soluble biopolymers and to transform them into soluble form.

The principally new method of the deep processing of rennet cheeses for receiving the melt cheese products without salts-smelters was elaborated. It differs from the traditional ones by the complete exclusion of the salts-smelters. This method is based on the use of the influence of freezing and fine-dispersed comminution on the raw material. It allows open biological potential of the rennet cheeses more fully and to extract the hidden (bound) protein forms from nanocomplexes of lipids and mineral substances. It allows destruct the proteins of rennet cheeses to the separate polymers and dipeptides and tripeptides. The used technological methods gave a possibility to exclude the salts-smelters at the rennet cheeses manufacturing. They favor the transformation of lipid-proteins paracaseinate calcium phosphate complexes to the separate amino acids and peptides and allow receive homogenous plastic mass.

It was established, that at the complex action of freezing and fine-dispersed comminution on the rennet cheese the destruction of hardly soluble lipid-protein nanocomplexes and release of protein from the bound state into free one - nanoform (by $33,5 \ldots 35 \%$ more) takes place. The mechanisms of this process, connected with cryomechanodestruction of connections between lipids and proteins and non-fermented catalysis of nanocomplexes were described.

It was established, that cryomechanodestruction and non-fermented catalysis of protein to the separate monomers $-\alpha$-amino acids (by 55...60\%) takes place at freezing and fine-dispersed comminution of rennet cheese before melting. The mechanism of freezing and non-fermented analysis, connected with cryomechanocracking of protein molecules at the expanse of peptide protein connections destruction to the separate $\alpha$-amino acids and their transformation into the free form was described. It was also demonstrated, that the conformational changes of protein molecules take place synchronously.

The offered and elaborated nanotechnology of melt cheese products on the base of rennet cheeses without salts-smelters includes complex action of freezing and fine-dispersed comminution. The mechanisms of processes, connected with cryomechanodestruction of connections between lipids and protein to the separate $\alpha$-amino acids are described.
} 
The cheese fillings for "Pancake" confectionary and cheese snacks - falafels were manufactured on the base of cheese mass, received using the new method and enriching vegetable nanoadditives. They exceed the well-known analogs by chemical composition and are remarkable for the storage life, increased in 2 times. At the same time the significant part of substances (BAS and biopolymers) in cheese filings is in nanodimensional form ( $55 \ldots 60 \%$ of protein), especially, free $\alpha$-amino acids, easily assimilated by the human organism. The recipes and technologies of sauces-dressings, sauces-deeps, cheese snacks and so on are also elaborated on the base of cheese mass, received by the new method.

Keywords: non-fermented analysis, mechanolysis, mechanical destruction, low-temperature, fine-dispersed comminution, rennet cheese, melt cheese products.

\section{Introduction}

The aim of the work is elaboration of the principally new method of the deep processing of rennet cheeses to the melting using the complex action of freezing and cryomechanolysis on the raw material that gives a possibility to destruct the hardly soluble biopolymers and transform them in soluble form.

The principally new method of deep processing of rennet cheese to melting and receiving the melt cheese products of health-improving purpose without salts-smelters was elaborated in Kharkiv state university of food and trade (city Kharkiv, Ukraine) at the department of fruits and vegetables processing in laboratory of "Innovative cryo- and nanotechnologies of vegetable additives and health-improving products" together with the specialists of Kharkiv college of processing and food industry of KNTUA named after P. Vasilenko (city Kharkov, Ukraine).

The offered method is based on the complex method of freezing and fine-dispersed comminution of the rennet cheese [1-10].This method leads to cryodestruction of heavily soluble paracaseinate calcium phosphate nanocomplexes in soluble form, their cryodestruction and transformation into soluble nanoform, release of protein from the state, bound with lipids in the free one, conformational change of protein molecules into separate polymers- $\alpha$-amino acids that allows realize melting process without salts-smelters [11-20].

Introduction of the new method of melt cheese products manufacturing using cryomechanolysis allows improve the quality of ready products, especially by harmlessness that is the absence of salts-smelters, harmful for human health and by the content of biologically active substances including antioxidant and immune modeling action.

\section{Materials and methods of the studies of low-molecular BAS and biopolymers at elabora- tion of the method of deep processing of rennet cheeses at preparation to the melting without salts-smelters}

\section{1. Studied material and equipment, used in experiments}

The cryogenic "shock" freezing of rennet cheeses was carried out using the modern experimental equipment, especially cryogenic program freezer with computer software (city Kharkiv, Ukraine) (Fig. 1) that functions using both cooling agent and inert medium of gas-like nitrogen. The cryogenic programmed freezer was elaborated by the National aerospace university, named after M. E. Zhukovsky "KAI" (city Kharkov, Ukraine) together with the joint authors of the article.

The elaborated method is suitable for any kind of rennet cheese at the melt cheese products manufacturing. The cryogenic processing of the rennet cheese was carried out at the temperature $-60{ }^{\circ} \mathrm{C}$ in fast refrigerator. The rennet cheese was frozen with the different speeds $\left(0,5 ; 2 ; 5^{\circ} \mathrm{C} / \mathrm{min}\right)$ to the final temperature in product $-18{ }^{\circ} \mathrm{C}$. The regimes of cryogenic processing were set earlier and presented in the work [3]. At the same time the freezing of $1 \mathrm{~kg}$ of cheese needed from 0,5 to 0,81 of liquid nitrogen depending on the thickness of frozen product. The volume of refrigerator by the raw material loading was $10 \mathrm{~kg}$.

The fine-dispersed comminution was carried out in comminutors (especially bedded, vibration-bedded mills, atritori of Ukrainian production and cutteri-activatori (France) at temperature not higher than $-10{ }^{\circ} \mathrm{C}$ to the particle size tens times more than at traditional comminution (to $50 \ldots 350 \mathrm{mcm}$ ). The studied problem is presented more fully in the monograph [3]. 


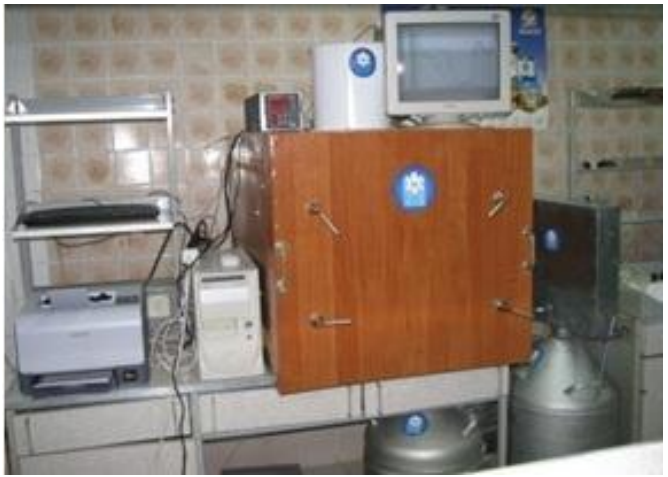

Fig. 1. Cryogenic programmed freezer with software

The rennet cheese was used as the object of research. The nanopowders of the natural spices (fragrant pepper, black pepper-pea, coriander), spicy (ginger, garlic) and carotenoid (carrot, paprika) vegetables were used as enrichment at elaboration of the recipes of fillings for "Pancake" confectionary and snacks on the base of elaborated cheese half-finished product (Fig. 2). At the same time the melt cheese mass after cryo-processing (or cheese half-finished product) and new health-improving melt cheese products such as fillings for the "Pancake" confectionary, received by nanotechnology and cheese snacks - falafels were studied (Fig. 3).

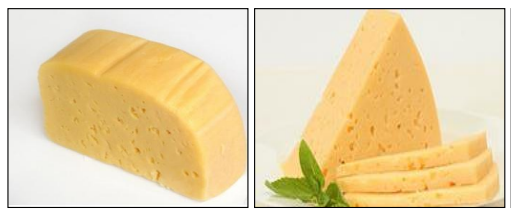

$a$

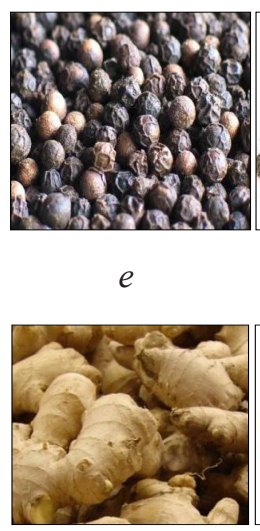

b

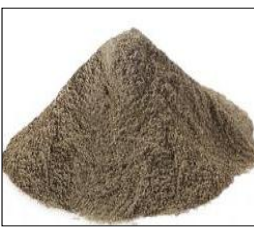

f

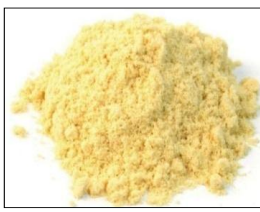

k

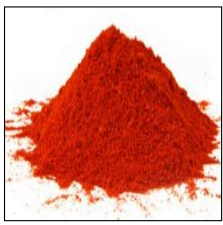

n

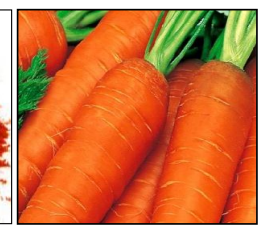

o

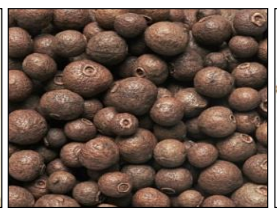

$c$

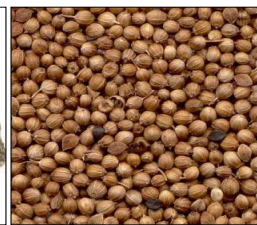

$g$

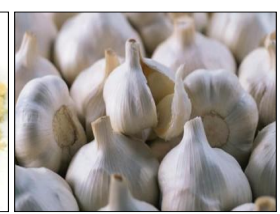

l

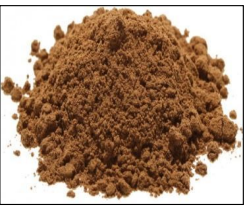

d

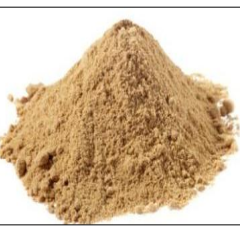

h

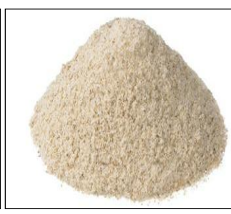

m

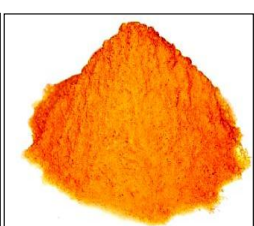

$p$

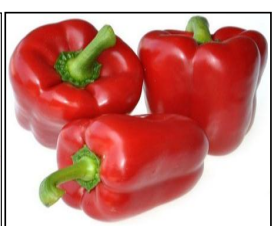

$r$

Fig. 2. Objects of research: $a$, $b$-samples of rennet cheese "Rossiysky"; $c-r$ - nanopowders, spices, spicy and carotenoid vegetables $(c$ - spice pepper, $d$ - nanopowder of spicy pepper; $e$ - black pepper-pea; $f$-nanopowder of black pepper-pea; $g$ - coriander; $h$ - nanopowder of coriander; $i$ - ginger; $k$ - nonapowder of ginger; $l$-garlic; $m$ - nanopowder of garlic; $n$ - carrot; $o$ - nanopowder of carrot; $n$ - paprika; $p$ - nanopowder of paprika 


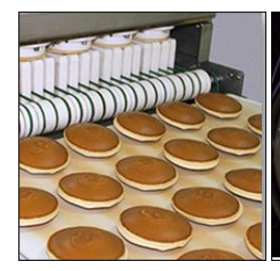

$a$

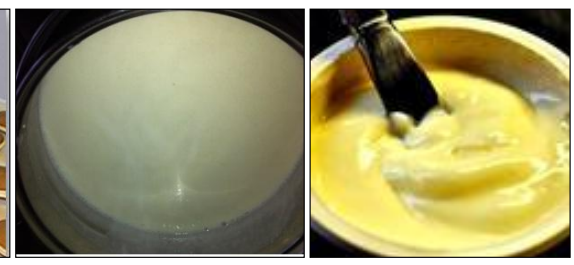

b c

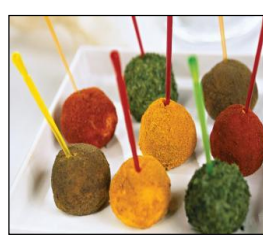

$d$

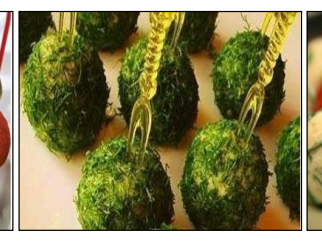

e

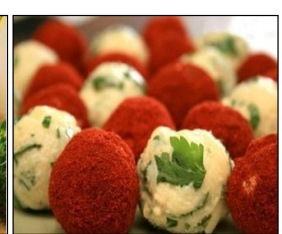

$f$

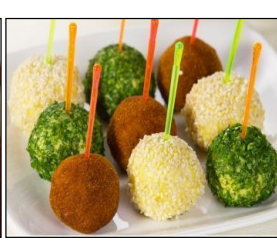

$g$

Fig. 3. Products of melt cheese: $a$ - "Pancake" confectionary with new cheese filling, elaborated by the authors; $b, c$ - paste-like melt cheese (half-finished product for filings, falafels, saucedressings, sauces-deeps and others); $d-g$ - cheese snacks-falafels ( $d$ - 'Assorti"; $e$ - "Smaragd";

$$
f-\text {-Pikantny"; } g-\text { "Exotic" }
$$

\section{2. Methods of determination of parameters of the studied samples}

The criteria of assessment of freezing and non-fermented catalysis at elaboration of the method of deep processing of the rennet cheese at its preparation to melting without salts-smelters and receiving of the melt cheese products of health-improving purpose on its base were set by determination of chemical substances in initial raw material and ready products, especially:

- protein, bound and free amino acids, hydrophilic and hydrophobic remains of amino acids, fat, dry substances;

- $\beta$-carotene, low-molecular phenol compounds (oxycoric acids), flavonol glycosides, catechins, tanning substances, aromatic substances.

At the same time the influence of freezing and non-fermented catalysis was controlled by determination of conformational changes of protein molecules (especially, radius, volume of kernel and coat, form of protein molecules and other).

The original methods of research namely, the method of determination of protein structure and conformational changes by E. G. Fisher was used for attaining the set aims alongside with conventional chemical, physical-chemical, spectroscopic, chromatographic ones.

The more detailed presentation of aforesaid methods of determination of indices of the studied samples can be seen in the works [20,22].

Experimental studies were carried out fivefold. The received results are presented in the units of international system CI.

The content of aromatic substances was determined by the quantity of scent by the method, based on the ability of chrome mixture to oxidate the essential oil. The content of aromatic substances in the product was determined by the quantity of consumed potassium bichromate and expressed in milliliters of sodium thiosulfate for $100 \mathrm{mg}(\mathrm{ml})$ of product [21].

\section{Results}

At elaboration of the method of deep processing of rennet cheese at its preparation to the melting without salts-smelters and receiving the melt cheese products on its base using freezing and fine-dispersed comminution it was important to increase the degree of destruction of heavily soluble paracaseinate calcium phosphate nanocomplexes of rennet cheeses in soluble gel form. It is known, that lipid paracaseinate calcium phosphate complexes give cheeses the hard texture that is not soluble at melting. In this connection the salts-smelters, harmful for human organism are used for their melting.

At the same time it was necessary to partially release protein from the state, bound with lipids into free one, realize conformational changes of protein molecules to the separate monomers- $\alpha$-amino acids. It was revealed, that $33 . .35 \%$ of protein in rennet cheeses are in the hidden, non-active, 
bound form [3]. It becomes possible at the expanse of freezing and non-fermented analysis - fine-dispersed comminution. It was also important to elucidate the mechanisms of aforesaid processes.

The authors revealed and demonstrated that the destruction of heavily soluble lipid-protein nanocomplexes and nanoassociates takes place at the complex action of freezing and fine-dispersed comminution on the raw material. At that the release (extracting) of protein from the bound, hidden, non-active state with lipid and mineral substances into the free state is by $33,3 \ldots 35,0 \%$ more than in initial raw material (Table 1).

Table 1

Influence of cryomechanolysis and freezing of hard rennet cheese on $\alpha$-amino acids content in free and bound state $(\mathrm{n}=3)$

\begin{tabular}{|c|c|c|c|c|c|c|c|c|}
\hline \multirow[b]{2}{*}{ Amino acid name } & \multicolumn{4}{|c|}{ Bound amino acids of hard rennet cheese } & \multicolumn{4}{|c|}{ Free amino acids of hard rennet cheese } \\
\hline & $\begin{array}{l}\text { In initial } \\
\text { cheese, } \\
\text { mg in } 100 \mathrm{~g}\end{array}$ & $\begin{array}{l}\text { After mechanolyh } \\
\text { sis and freezing, } \\
\text { mg in } 100 \mathrm{~g}\end{array}$ & $\begin{array}{c}\% \text { of } \\
\text { initial }\end{array}$ & $\begin{array}{c}\text { Increase } \\
\text { of initial, } \\
\text { times }\end{array}$ & $\begin{array}{l}\text { In initial } \\
\text { cheese, } \mathrm{mg} \\
\text { in } 100 \mathrm{~g}\end{array}$ & $\begin{array}{l}\text { After mechanolyh } \\
\text { sis and freezing, } \\
\text { mg in } 100 \mathrm{~g}\end{array}$ & $\begin{array}{c}\% \text { to } \\
\text { initial }\end{array}$ & $\begin{array}{c}\text { Increase } \\
\text { to initial, } \\
\text { times }\end{array}$ \\
\hline Valine & 450 & 1080 & 240,0 & 2,4 & 340 & 960 & 282,3 & 2,8 \\
\hline Isoleucine & 920 & 2100 & 228,0 & 2,3 & 650 & 1250 & 192,0 & 1,9 \\
\hline Leucine & 2300 & 2550 & 111,0 & 1,1 & 130 & 250 & 192,0 & 2,0 \\
\hline Lysine & 1240 & 3140 & 253,2 & 2,5 & 360 & 550 & 153,0 & 1,5 \\
\hline Methionine & 1040 & 1120 & 108,0 & 1,1 & 400 & 600 & 150,0 & 1,5 \\
\hline Threonine & 710 & 1240 & 175,0 & 1,7 & 120 & 240 & 200,0 & 2,0 \\
\hline Tryptophan & 700 & 700 & 100,0 & 1,0 & 400 & 400 & 100,0 & 1,0 \\
\hline Pheenylalanine & 1070 & 1480 & 138,0 & 1,4 & 230 & 640 & 278,0 & 2,8 \\
\hline Arginine & 1910 & 1300 & 67,9 & - & 430 & 870 & 202,0 & 2,0 \\
\hline Aminosuccinic acid & 1330 & 2310 & 174,0 & 1,7 & 200 & 490 & 245,0 & 2,5 \\
\hline Gestinin & 1010 & 1240 & 123,0 & 1,2 & 80 & 150 & 188,0 & 1,9 \\
\hline Glycine & 410 & 560 & 137,0 & 1,4 & 70 & 140 & 200,0 & 2,0 \\
\hline Glutamic acid & 4410 & 4700 & 107,0 & 1,1 & 1620 & 1790 & 110,0 & 1,1 \\
\hline Proline & 1720 & 2760 & 160,0 & 1,6 & 60 & 150 & 250,0 & 2,5 \\
\hline Serine & 1100 & 1840 & 167,0 & 1,7 & 310 & 370 & 119,0 & 1,2 \\
\hline tyrosine & 2210 & 1630 & 73,7 & - & 240 & 340 & 142,0 & 1,4 \\
\hline Cystine & 300 & 300 & 100,0 & 1,0 & 540 & 420 & - & - \\
\hline Alanine & 580 & 1200 & 207,0 & 2,1 & 90 & 260 & 289,0 & 2,9 \\
\hline Totally & 23410 & 31250 & 33,5 & 1,33 & 6270 & 9870 & 57,4 & 1,57 \\
\hline
\end{tabular}

For example, $100 \mathrm{~g}$ of initial rennet cheese contains 23,4 $\mathrm{g}$ of bound amino acids and in frozen and fine-dispersed state it contains $31,2 \mathrm{~g}$. The mechanism of this process, connected with cryomechanocracking, mechanodestruction (destruction) of connections between lipids and proteins was established and revealed at the research. This process of destruction of nanocomplexes and nanoassociates of biopolymers is connected with non-fermented catalysis (destruction), cryodestruction and cryomechanolysis.

It was also established, that non-fermented cryocatalysis (destruction) of proteins to monomers of free $\alpha$-amino acids is by $55-60 \%$ at the processing of rennet cheeses using the complex action of freezing and fine-dispersed comminution. It was revealed, that the part of $\alpha$-amino acids of rennet cheese transforms from the bound form into free one at cryomechanolysis and freezing. Thus, the mass part of free $\alpha$-amino acids in frozen fine-dispersed paste-like cheeses was increased in 1,1...2,9 times (comparing with its quantity in initial hard rennet cheese before the low-temperature comminution).

At the same time it was revealed, significant conformational changes of protein molecules, decrease of the mass part of hydrophilic (HFL) remains of amino acids $\left(\mathrm{C}_{n}\right),\left(\mathrm{C}_{\mathrm{hn}}\right)$ and decrease of ratio between them $\left(\mathrm{C}_{\mathrm{n}} / \mathrm{C}_{\mathrm{hn}}\right)$ take place at freezing and cryodestruction in parallel with the destruction of the part of protein to the separate amino acids and simple peptides.

It was established, that freezing and cryodestruction lead to the decrease of size and change of protein molecules and also to the change of radius, volume of protein molecule, radius of its kernel and also to the decrease of the rate of kernel filing with hydrophilic remains. At the same time 
the form of protein molecules is changed. According to E. G. Fisher's theory, it was established, that the molecules of initial hard rennet cheese have the ellipsoid form and after cryomechanolysis and freezing they look as supramolecular structures. It favors the increase of accessibility, solubility, peptization of protein molecules at preparation of the rennet cheeses to the melting and receiving of the homogenic liquid gel texture of the cheese mass.

Nanotechnology of the melt cheeses manufacturing using rennet cheeses was elaborated with exclusion of salts-smelters. It provides freezing of the rennet cheese to the temperature $-18{ }^{\circ} \mathrm{C}$ and its fine-dispersed comminution at the temperature no less than $10{ }^{\circ} \mathrm{C}$ to the particles in several times less than at traditional comminution to the size $50 \ldots 350 \mathrm{mcm}$. This technology also includes the process of pasteurization (at temperature $70 \ldots 75^{\circ} \mathrm{C}$ ), melting (without salts-smelters) and homogenization. Traditional technologies of melt cheeses are presented in the monograph [3].

The cheese filings for "Pancake" confectionary and cheese snacks - falafels were elaborated on the base of melt cheese mass of rennet cheeses, received using the described method. The elaborated recipes of the new cheese products (filings and falafels) contain components, presented on the Fig. 2. There are nanopowders of fragrant pepper, black pepper-pea, coriander, ginger, garlic, carrot (or pumpkin), paprika, elaborated by the authors of this article.

The introduction of aforesaid vegetable additives with the high content of BAS such as terpenoids (aromatic substances, essential oils, carotenoids and so on) and phenol compounds into the melt cheese products allows enrich the cheese products with the vegetable BAS. It was established by scientific way, that it allows increase the storage life in 2,5-3,0. Technology of cheese filings for "Pancake" confectionary is introduced into the serial production at enterprise "Wooden Tale" LTD (city Kharkiv, Ukraine).

The cheese filings (Table 2) for "Pancake" confectionary, enriched with vegetable nanoadditives, are remarkable for the high content of aromatic substances $(15,3 \ldots 37,5 \mathrm{mg}$ of sodium thiosulfate in $100 \mathrm{~g}$ ), general phenol compounds (by chlorogenic acid) $(25,1 \ldots 27,8 \mathrm{mg}$ in $100 \mathrm{~g}$ ), flavonol glycosides $(5,3 \ldots 6,7 \mathrm{mg}$ in $100 \mathrm{~g})$, free catechins $(5,2 \ldots 6,5 \mathrm{mg}$ in $100 \mathrm{~g})$, tanning substances $(33,8 \ldots 61,1 \mathrm{mg}$ in $100 \mathrm{~g}), \beta$-carotene $(3,0 \ldots 3,5 \mathrm{mg}$ in $100 \mathrm{~g})$. These compounds have potential immune modeling, antioxidant, detoxicating and anti-tumor properties $[3,19]$.

Table 2

Content of biologically active substances, protein and irreplaceable amino acids in the cheese filings for "Pancake" confectionary, enriched with vegetable nanoadditives, created by nanotechnology $(n=3)$

\begin{tabular}{|c|c|c|c|c|}
\hline \multirow{2}{*}{ Parameter name } & \multicolumn{4}{|c|}{$\begin{array}{l}\text { Melt cheese filings, enriched with vegetable nanostructured additives, } \\
\text { produced by nanotechnology }\end{array}$} \\
\hline & $\begin{array}{l}\text { "Cheese with } \\
\text { garlic"* }\end{array}$ & $\begin{array}{l}\text { "Cheese with } \\
\text { garlic and bacon"* }\end{array}$ & $\begin{array}{l}\text { "Cheese with } \\
\text { mushrooms"* }\end{array}$ & $\begin{array}{l}\text { "Cheese with } \\
\text { vegetables"* }\end{array}$ \\
\hline Protein, \% & 28,7 & 26,6 & 24,6 & 22,5 \\
\hline \multicolumn{5}{|c|}{ Irreplaceable amino acids, $\mathrm{mg}$ in $100 \mathrm{~g}$} \\
\hline Valine & 1428 & 1326 & 1224 & 1122 \\
\hline Isoleucine & 2345 & 2177,5 & 2010 & 1842,5 \\
\hline Leucine & 1960 & 1820 & 1680 & 1540 \\
\hline Lysine & 2583 & 2398,5 & 2214 & 2029,5 \\
\hline Methionine & 1204 & 1118 & 1032 & 946 \\
\hline Threonine & 1036 & 962 & 888 & 814 \\
\hline Tryptophan & 770 & 715 & 660 & 605 \\
\hline Pheenylalanine & 1484 & 1378 & 1272 & 1166 \\
\hline$\beta$-carotene, $\mathrm{mg}$ in $100 \mathrm{~g}$ & 3,0 & 3,1 & 3,5 & 3,2 \\
\hline Phenol compounds (by chlorogenic acid), mg in $100 \mathrm{~g}$ & 25,1 & 27,8 & 26,4 & 25,8 \\
\hline Flavonol glycoside (by rutin), mg in $100 \mathrm{~g}$ & 5,3 & 6,5 & 5,5 & 6,7 \\
\hline Free catechins (by d-catechin) & 5,4 & 6,1 & 5,2 & 6,5 \\
\hline Tanning substances (by tannin), $\mathrm{mg}$ in $100 \mathrm{~g}$ & 61,1 & 33,8 & 45,6 & 38,4 \\
\hline Aromatic substances, $\mathrm{mg} \mathrm{Na}_{2} \mathrm{~S}_{2} \mathrm{O}_{3}$ & 37,5 & 15,3 & 28,4 & 32,9 \\
\hline Fat, $\%$ & 20,0 & 21,2 & 23,4 & 24,6 \\
\hline Dry substances, $\%$ & 69,9 & 70,0 & 65,4 & 63,8 \\
\hline
\end{tabular}

Note: *-the composition of filings is a property of the author of article 


\section{Conclusions}

Thus, the principally new method of cheese products manufacturing, elaborated by the authors excludes the salts-smelters. It includes the processes of freezing, mechanodestruction and non-fermented catalysis that allows realize the destruction of heavily soluble lipid-protein nanocomplexes of rennet cheeses and to carry out their melting without the salts-smelters.

It was demonstrated, that the melt cheese products contain biopolymers in easily assimilated nanoform that can not be received using traditional methods of melt cheeses that included the cheeses comminution on the cutter-comminutor to the particle size $50 \ldots 350 \mathrm{mcm}$.

It gives a possibility to receive the health-improving melt cheeses on the base of rennet cheese with principally new chemical composition without salts-smelters and with higher assimilability by the human organism. In their turn they can be used at elaboration of the functional health-improving products of mass food on the base of rennet cheese such as: snacks, filings, sauces and so on.

At the same time the introduction of vegetable enriching additives of the natural spicery and spicy vegetables with significant part of BAS with immune modeling and antioxidant properties allowed receive the health-improving melt cheese filings. $100 \mathrm{~g}$ of filling includes $1 / 2$ of the day need in $\beta$-carotene and day norm of phenol compounds. The introduction of nanopowders of the natural spicery gave a possibility to increase the storage life of melt cheese additives in 2 times comparing with traditional products. The analysis of chemical composition allows relate the new melt cheese products to the health-improving food.

But in further it is planned to search for the other methods of activation, disintegration of non-active hidden forms of nanocomplexes of biopolymers of rennet cheeses at preparation for the melting, namely by regulation of $\mathrm{pH}$ medium, enrichment with the different vegetable additives with the high BAS content and so on.

\section{References}

[1] FAO/WHO/UNU. Globalnaya strategiya po pitaniyu, fizicheskoy aktivnosti i zdorov'yu - 2004 (2004). RezolyutsiyaWHA.55.23 prinyata sessiey Vsemirnoy assamblei zdravoohraneniya (VAZ), World Health Organization.

[2] FAO/WHO/UNU. Dietary protein quality evalution in human nutrition. Report of an FAO Expert Consultation (2013). Food and agriculture organization of the united nations Rome, 92-57.

[3] Pavlyuk, R. Yu., Pogarska, V. V., Yur'eva, O. O., Pavlyuk, V. A. et. al. (2014). Krio- I mehanohImIya v harchovih tehnologIyah. Kharkiv: Finart, 260.

[4] Giri, A., Kanawjia, S. K., Rajoria, A. (2014). Effect of phytosterols on textural and melting characteristics of cheese spread. Food Chemistry, 157, 240-245. doi: 10.1016/j.foodchem.2014.01.127

[5] Rudavs'ka, H. B., Holub, B. O. (1999). Ozdorovchi produkty KhKhI storichchya, 4, 42-45.

[6] Boisard, L., Andriot, I., Martin, C., Septier, C., Boissard, V., Salles, C., Guichard, E. (2014). The salt and lipid composition of model cheeses modifies in-mouth flavour release and perception related to the free sodium ion content. Food Chemistry, 145, 437-444. doi: 10.1016/j.foodchem.2013.08.049

[7] McCarthy, C. M., Wilkinson, M. G., Kelly, P. M., Guinee, T. P. (2016). Effect of salt and fat reduction on proteolysis, rheology and cooking properties of Cheddar cheese. International Dairy Journal, 56, 74-86. doi: 10.1016/j.idairyj.2016.01.001

[8] Hougaard, A. B., Sijbrandij, A. G., Varming, C., Ardö, Y., Ipsen, R. (2015). Emulsifying salt increase stability of cheese emulsions during holding. LWT - Food Science and Technology, 62 (1), 362-365. doi: 10.1016/j.lwt.2015.01.006

[9] Amamcharla, J. K., Metzger, L. E. (2015). Prediction of process cheese instrumental texture and melting characteristics using dielectric spectroscopy and chemometrics. Journal of Dairy Science, 98 (9), 6004-6013. doi: 10.3168/jds.2015-9739

[10] Katarzyna, K. (2008). Czynniki kształtujące teksturę serów topionych. ŻYWNOŚĆ. Nauka. Technologia. Jakość, 3 (58), 5-17. 
[11] Cichosz, G. (2000). Technologia serów topionych. Warszawa: Hoża, 255.

[12] Szczesniak, A. S. (2002). Texture is a sensory property. Food Quality and Preference, 13 (4), 215-225. doi: 10.1016/s0950-3293(01)00039-8

[13] Baramboym, N. K. (1978). Mehanohimiya vyisokomolekulyarnyih soedineniy. Moscow: Himiya, 384.

[14] Allen Foegeding, E., Brown, J., Drake, M., Daubert, C. R. (2003). Sensory and mechanical aspects of cheese texture. International Dairy Journal, 13 (8), 585-591. doi: 10.1016/s09586946(03)00094-3

[15] Tamime, A. Y. (2011). Processed Cheese and Analogues: An Overview. Blackwell Publishing Ltd, 24.

[16] Surówka, K. (2002). Tekstura żywności i metody jej badania. Przem. Spoż., 10, 12-17.

[17] Pavlyuk, R. Yu., Cherevko, A. I., Gulyiy, I. S. et. al. (1997). Novyie tehnologii vitaminnyih uglevodsoderzhaschih fitodobavok $\mathrm{i}$ ih ispolzovanie v produktah profilakticheskogo deystviya. Kharkiv; Kyiv, 285.

[18] Pogarskaya, V. V., Pavlyuk, R. Yu., Cherevko, A. I., Pavlyuk, V. A., Maksimova, N. F. (2013), Aktivatsiya gidrofilnyih svoystv karotinoidov rastitelnogo syirya. Kharkiv: FInart, 345.

[19] Pavlyuk, R. Yu., Pohars'ka, V. V., Radchenko, L. O., Yur»yeva, O. O., Hasanova, H. E., Abramova, T. S., Kolomiyets', T. M. (2015). The development of technology of nanoextracts and nanopowders from herbal spices for healthful products. Eastern-European Journal of Enterprise Technologies, 3 (10 (75)), 54-59. doi: 10.15587/1729-4061.2015.43323

[20] Pavlyuk, R., Pogarska, V., Pavlyuk, V., Balabai, K., Loseva, S. (2016). The development of cryogenic method of deep treatment of inulin-containing vegetables (topinambour) and obtaining of prebiotics in the nanopowders form. EUREKA: Life Sciences, 3, 36-43. doi: 10.21303/2504-5695.2016.00145

[21] Produktyi pererabotki plodov i ovoschey. Chislo aromata: GOST 8756.77-70 (1990). Moscow: Izd-vo standartov, 15.

[22] Pavlyuk, R., Pogarska, V., Radchenko, L., Roman, D. T., Timofeyeva, N., Kotuyk, T. (2016). The new method of processing of carotene-containing vegetables for the production of nanoproducts using combi-steamers and fine-dispersed comminution. EUREKA: Life Sciences, 3, 44-49. doi: 10.21303/2504-5695.2016.00146 